5. Parsons-Smith BG, Summerskill WHJ, Dawson AM, et al. The electroencephalograph in liver disease. Lancet 1957;273:867-71.

6. Van der Rijt CC, Schalm SW, De Groot GH, et al. Objective measurement of hepatic encephalopathy by means of automated EEG analysis. Electroencephalogr Clin Neurophysiol 1984;57:423-36.

7. Amodio P, Marchetti P, Del Piccolo F, et al. Spectral versus visual EEG analysis in mild hepatic encephalopathy. Clin Neurophysiol 1999;110:1334-44.

8. Gugino LD, Chabot RJ, Prichep LS, et al. Quantitative EEG changes associated with loss and return of consciousness in healthy adult volunteers anaesthetized with propofol or sevoflorane. Br J Anaesth 2001;87:421-8.

9. Rampil IJ. A primer for EEG signal processing in anesthesia. Anesthesiology 1998;89:980-1002

10. Riker RR, Fraser GL, Simmons LE, et al. Validating the sedation-agitation scale with the bispectral index and visual analog scale in adult ICU patients after cardiac surgery. Intensive Care Med 2001;27:853-8.

11. Teasdale G, Jennett B. Assessment of coma and impaired consciousness. A practical scale. Lancet 1974;ii:81-4.

12. Pugh RN, Murray-Lyon IM, Dawson JL, et al. Transection of the oesophagus for bleeding oesophageal varices. Br J Surg 1973;60:646-9.

13. Kamath PS, Wiesner RH, Malinchoc M, et al. A model to predict survival in patients with end-stage liver disease. Hepatology 2001;33:464-70.

14. Bossuyt PM, Reitsma JB, Bruns DE, et al. The STARD statement for reporting studies of Diagnostic Accuracy: explanation and elaboration. Clin Chem 2003;49:718.

15. Kim DW, Kil HY, White PF. The effect of noise on the bispectral index during propofol sedation. Anesth Analg 2001;93:1170-3.
16. Nieuwenhuijs D, Coleman EL, Douglas NJ, et al. Bispectral index values and spectral edge frequency at different stages of physiologic sleep. Anesth Analg 2002;94:125-9.

17. Bruhn J, Bouillon TW, Shafer SL. Electromyographic activity falsely elevates the bispectral index. Anesthesiology 2000;92:1485-7

18. Krisper $\mathbf{P}$, Haditsch B, Stauber R, et al. In vivo quantification of liver dialysis: comparison of albumin dialysis and fractionated plasma separation. J Hepatol 2005; 43:451-7.

19. Hanley JA, McNeil BJ. The meaning and use of the area under a receiver operating characteristic (ROC) curve. Radiology 1982;143:29-36.

20. Kullmann F, Hollerbach S, Lock G, et al. Brain electrical activity mapping of EEG for the diagnosis of (sub) clinical hepatic encephalopathy in chronic liver disease. Eur J Gastroenterol Hepatol 2001;13:513-22.

21. Shawcross D, Jalan R. The pathophysiologic basis of hepatic encephalopathy: central role for ammonia and inflammation. Cell Mol Life Sci 2005:62:2295-304.

22. Haussinger D. Low grade cerebral edema and the pathogenesis of hepatic encephalopathy in cirrhosis. Hepatology 2006;43:1187-90.

23. Quero JC, Hartmann IJ, Meulstee J, et al. The diagnosis of subclinical hepatic encephalopathy in patients with cirrhosis using neuropsychological tests and automated electroencephalogram analysis. Hepatology 1996;24:556-60.

24. Sleigh JW, Steyn-Ross DA, Steyn-Ross ML, et al. Comparison of changes in electroencephalographic measures during induction of general anaesthesia: influence of the gamma frequency band and electromyogram signal. Br J Anaest 2001;86:508.

25. Ong JP, Aggarwal A, Krieger D, et al. Correlation between venous ammonia levels and the severity of hepatic encephalopathy. Am J Med 2003;114:188-93.

\section{Liver failure during pregnancy}

This is an introduction to the Gut tutorial "Liver failure during pregnancy" hosted on BMJ Learning-the best available learning website for medical professionals from the BMJ Group.

This module discusses the clinical management of acute liver failure occurring in pregnancy. Early recognition of possible causes and prompt treatment are crucial for successful outcome. Differentiating pregnancy-related liver dysfunction from liver dysfunction due to causes unrelated to pregnancy is often not possible clinically. Clinical criteria, used to diagnose the cause of liver dysfunction antenatally, often overlap. Clinical decision making in this setting has to be carried out within the constraints of not being able to make a precise diagnosis antenatally. If acute liver failure due to a pregnancy-related cause (such as acute fatty liver of pregnancy) is a possible differential diagnosis, urgent delivery of the baby is warranted. The association of inherited fatty acid oxidation disorders and maternal liver disease is being increasingly recognised. However, the exact mechanism of this foetal-maternal interaction is not yet known. Awareness of this association is important in providing counselling about the risk of maternal liver disease in subsequent pregnancies and deciding need for any specific therapy in the baby.

To access the tutorial (Interactive Case History), click on BMJ Learning: take this module on BMJ Learning from the content box at the top right and bottom left of the online article. For more information please go to: http://gut.bmj.com/tutorials/ collection.dtl

If prompted, subscribers must sign into Gut with their journal username and password. All users must also complete a onetime registration on BMJ Learning and subsequently log in (with a BMJ Learning username and password) on every visit.

\section{E Eapen, ${ }^{1}$ B Ramakrishna, ${ }^{2}$ R Jose, ${ }^{3}$ G Loganathan, ${ }^{1}$ G Chandy ${ }^{1}$}

${ }^{1}$ Department of Gastrointestinal Sciences, Christian Medical College, Vellore, Tamil Nadu, India; ${ }^{2}$ Department of Pathology, Christian Medical College, Vellore, Tamil Nadu, India; ${ }^{3}$ Department of Obstetrics and Gynaecology, Christian Medical College, Vellore, Tamil Nadu, India

Correspondence to: Dr C E Eapen, Department of Gastrointestinal Sciences, Christian Medical College, Vellore, Tamil Nadu, India, 632004; eapen@cmcvellore. ac.in

Competing interests: None.

Gut 2008;57:83. doi:10.1136/gut.2007.143305 